Karimov R., Dargahov V. (2015). Study of profitability of organization of tourism routes (on the example of Sheki-Zagatala Economic Region of Azerbaijan). Copernican Journal of Finance \& Accounting, 4(1), 71-81. http://dx.doi.org/10.12775/CJFA.2015.005

\author{
Rovshan Karimov* \\ Azerbaijan National Academy of Sciences
}

Vugar Dargahov**

Baku State University

\title{
STUDY OF PROFITABILITY OF ORGANIZATION OF TOURISM ROUTES (ON THE EXAMPLE OF SHEKI-ZAGATALA ECONOMIC REGION OF AZERBAIJAN)
}

Keywords: profitability, price, favorable, region, tourism, tour planning.

J E L Classification: M31, L83, R11, R58.

\begin{abstract}
This paper is devoted to economical substantiation of organization of touristic routes, and relevant activities of tour operators in terms of profitability. Currently, rational use of local natural and man-made recreational resources, as well as successful business activity in tourism can be reached considerably due to effectively-organized touristic routes. The organization of such tours seems efficient for tour operators which may gain more benefit from collective forms of the excursions. However, it is important for a company organizing touristic route to function more effectively and gain real profit with considering primary costs, tax paying and other conditions in tourism market. In this connection, ways of measuring relevant expenditure are investigated in this paper. The study is carried out on the example of Sheki-Zagatala, the advanced to-
\end{abstract}

Date of submission: April 26, 2015; date of acceptance: May 11, 2015.

* Contact information: rovshan_karimov@yahoo.com, Institute of Geography after acad. H.A. Aliyev, Azerbaijan National Academy of Sciences, H.Javid str. 31, Az1143, Baku, Azerbaijan, phone: +994125393361.

** Contact information: Baku State University 23 Zahid Khalil, Az1073/1, Baku, Azerbaijan. 
urism region of Azerbaijan Republic in order to substantiate profitability of organizing touristic route in practice.

The research objective of the paper is to find more effective and profitable way of organizing touristic routes and evaluate relevant profitability limit for tour operators. For this purpose, prior measuring, planned measuring, individual calculation, and rent per tour were used as applicable methods. The results of the research show that rent per tour should be based as an effective way of evaluation of profitability, where main and variable expenditures, as well as incomes of a company must be taken into consideration. Meanwhile, the existing and recommended local routes in Sheki-Zagatala are shown and offered, with the analysis of the local natural and man-made recreational resources. Recommendations on improvement of organization of tours are offered as well.

Translated by Rovshan Karimov and Vugar Dargahov

\section{IIIINTODUCTION}

In the regions of the Republic of Azerbaijan with their attractive landscapes and cultural heritage, tourism play significant role in economic development of the country and its regions (Dargahov 2008).

Planning of tourism routes (tours) within a country is one of topical issues in connection with the increasing interest to rest and cognitive types of tourism in recent years. Selling of relevant tour package at favorable prices should be regarded as a main factor in attracting of large number of tourists. Tours offered to potential customers must be fair and also suiting whereas prices in some cases may not be in accordance with rendered services and offered tours (Dargahov 2012).

In many mountainous regions of Azerbaijan, organization of tours by touristic buses seems possible and efficient due to such factors as relief peculiarities, the existence of different natural resources of tourism importance, and interests of visitors who prefer see sightseeing and reach destination within a short time. Organization of these routes enables clients see sightseeing in safer and more comfortable condition as well as during shorter time.

In the Sheki-Zagatala economic region chosen as a research object of this work, the planning and diversification of tours is more topical compared to other regions of Azerbaijan. Sheki-Zagatala is the second most-visited tourism region in the country if taking into consideration only domestic tourists.

However, a tourism company must determine appropriate price for tour intended for a group of tourists. This price must be fair, in other word suitable for customer (client) and in the meantime, beneficial for a tourism company. 
The research objective of this paper is to find more effective and profitable way of organization of touristic routes. The study has practical importance not only for the Sheki-Zagatala region but also for all tourism companies engaged in organization of collective tours within a region. The study is carried out with implementation of marketing analysis, consideration of recreational potential, and substantiation of new offered tourism routes in the Sheki-Zagatala economic region.

\section{THE RESEARCH METHODOLOGY AND THE COURSE OF THE RESEARCH PROCESS}

Tour planning includes the following stages: definition of work scheme of a tour operator; identification of subjects responsible for the organization of services included into a tour package, and conclusion of a contract; determination of price of a tour and relevant services in market. Price-defining factors are taken into account by tour operator in its price strategy.

Price-forming factors are taken into consideration by an operator of tour in price strategy. As Dargahov (2012) indicates, this strategy is composed of actions of a company, considering: a) determination of different prices and modifications of a planned tour; b) sustainability of functioning of an operator in tourism market; c) opportunity of gaining income as high as much; d) occupation of definite place and strengthening of position in tourism market.

There are different ways of calculation of price of a tour. The one of them is 'prior measuring'. Thus, measuring can be conducted in case of determination of exact price of a tour before realization of tourism product in market. This method is practiced mainly regarding to private tours, and includes simply measuring prices of services rendered by relevant specialized companies. Such approach allows calculating costs spent by companies for preparation of tours (Ilyina 2002).

Another method of measuring of price of a tour is 'planned measuring'. When using this method, price of a tour typically is not concrete until this tour as a product is considered to be sold. Planned calculation can be implemented chiefly with purpose of organizing collective tours. In this process, prices remain inexact before how many tourists are in a group is clear. Moreover, soft prices on transportation, excursion, or accommodation are also not exactly clear before selling of tour. Tourism operator determines critical point of profitability of a definite action, with taking into consideration planned norm of profit, as well as least number of tourists equivalent to zero profitability. Low- 
est figure of profitability is derived by: multiplying number of known clients with amount of 'changing expenditure' (I); then adding gained sum on amount of expenditures (II); and by equalizing this gained figure with total price of sending of tourists (measured by multiplying numbers of individual tours with their prices) (III). This formula is supported by Ushakov (2006):

$\mathrm{B} \cdot \mathrm{K}+\mathrm{A}=\mathrm{P} \cdot \mathrm{K}$, where

$\mathrm{B}$ indicates amount of changing expenditure; $\mathrm{K}$ is number of sent tourists; $\mathrm{A}$ is amount of permanent expenditure; while $\mathrm{P}$ indicates determined (declared) price of one tour (sending).

Based on this formula, lowest number of sent tours as limit of profitability can be defined as:

$$
\mathrm{K}=\mathrm{A} /(\mathrm{P}-\mathrm{B}) \cdot 100
$$

The last formula is usable in practice. Calculation of zero profitability has importance as it enables a company to determine least number of tourists as beneficial number of customers, to which tours can be sold in order to function without loss. Permanent expenditures of tourism operator include office leasing, municipal expenses, salaries of worker whereas changing expenditures are measured with consideration of costs of sold tours. Thus, price of tourism product can be determined in different ways.

Usually, tourism agencies prefer to take into account prime cost when calculating price of a tour. They typically buy package of services relevant to tour on cooperative prices. In this case, providing of services in accordance with ordered and package-form tours is profitable as it is cheaper way of relevant functioning for a company (Ilyina 2002).

Package and inclusive prices may be intended for a full complete set of a tour, composed of many tourism services. Tariffs of tour operators usually include commission costs and commercial interests of tour agencies, and are determined in accordance with level and quality of concrete services of relevant companies (Ilyina 2004). Prices are changing depending on number of customers, and are different for customers and group of tariffs. Individual price may be determined for tourist individually.

In order to determine economic rent of tourism product, method of 'individual calculation' is considered to be suitable (Zdorov 2007). Such individual cal- 
culation allows define continuity of an offered tour in tourism market. Taking this into account, conformity of services to requirement as well as profitability of attracting tourists in least number in market can be determined.

\section{RESULTS OF MARKETING ANALYSIS}

Marketing analysis of tourism market shows that most of customers are between 26-55 years of age. Tourists, visiting Sheki-Zagatala are mainly from Baku urban area. In terms of income, visitors on Sheki-Zagatala can be classified as tourists with "medium and high" income. Tourists typically spend 3-5 days in average in the region which nearly equates to the corresponding figure fixed by overall country. Tourists who visited Sheki-Zagatala have become familiar with this area due to conversation with their friends, relatives or colleagues, and partially by watching TV and via internet (Tourism in Azerbaijan 2006). This indicates to the low level of advertising activity. On the other side, weak relationship and cooperation between tourism companies and recreation centers negatively affects the development of tourism both in Sheki-Zagatala as well as other regions of the country. In this regard, as we think, tourism companies and accommodation centers should function on the basis of cooperative contracts. Cooperation between these two sides may allow efficiently organize the process of organization of tours and accommodate tourists at hotels and recreation centers more rationally and on favorable terms. Such cooperation also would give an impetus to different types of tourism and more efficiently use tourism potential of the region in general.

Sheki-Zagatala is the second marketarea of Azerbaijan after Guba-Khachmaz in terms of meeting requirements of population of Baku for trip with tourism purpose. As a result of the increased attention to Sheki-Zagatala as a destination, hotels and recreation centers of the region have seen dynamic rise in recent years.

Analysis, conducted on interests of tourists visiting Sheki-Zagatala shows that rest tourism, business tourism and rural tourism are spread (over $80 \%$ of visitors) as the major types in the region (Economic passport 2012). This finds its reflection on Figure 1. 
Figure 1. Classification of visitors of Sheki-Zagatala depending on their purpose (in percent)

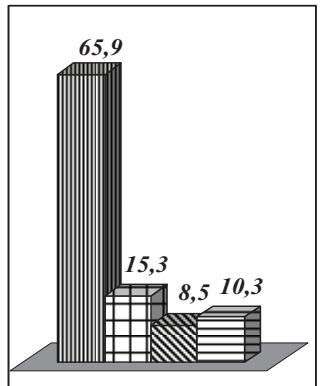

2010

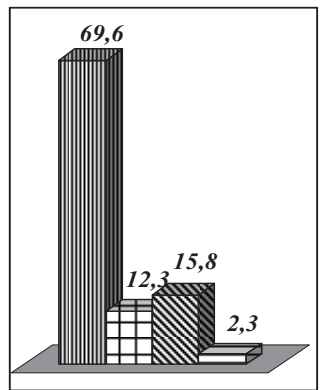

2011

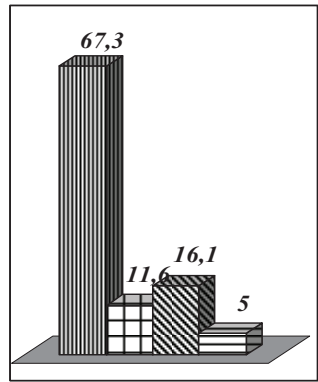

2012

m Resting

田 Business

$\mathbb{Q}$ Rural tourism

Other

S o u r c e : Statistics of tourism $(2011,2012,2013)$, Yearbooks of State Statistical Committee of Azerbaijan Republic.

It is notable that taking into consideration wide experience of foreign countries in rural tourism, routes to be planned in the future, may considerably influence on commercial advertising of villages in Sheki-Zagatala (Dargahov, Karimov 2012).

In recent years, area of activity and also capability of hotels and recreation centers have been increased in the region. The growth of number of tourists has been observed as well. Tourists prefer Gabala, Sheki, Gakh and Zagatala as the destinations, whereas the number of hotels from larger to less is changing by the same succession in these regions. $48 \%$ of hotels and recreation centers are situated in Gabala.

As analysis of perennial statistic data shows, the number of visitors is increasing in Sheki-Zagatala. In 2012, the number of tourists made up 67,5 thousand persons whereas in 2006 it was only 16,3 thousand. Sheki-Zagatala adopted $2 \%$ of overall tourists in the country whereas in 2006 the corresponding indicator made $5,6 \%$. However, these figures are not high considering the existing potential of Sheki-Zagatala which is rich in natural recreational resources. This is because the rest regions of Azerbaijan are also attracting high number of tourists.

In the region, annual tourist capacity of accommodations has made up 1238 in 2000, 5228 in 2006, 5219 in 2009, and 8327 in 2013. The share of accommo- 
dations of Sheki-Zagatala in relation to the country has been increased by 5,4\% in 2012 and 9,4\% in 2013 (Statistics of tourism 2014).

As for the tourism routes in Sheki-Zagatala, first of all, it should be noted that there are some problems concerning the organization of local tours, faced by companies. Most urgent of them are the following:

- The spread of less-developed highway infrastructure in settlements, included into the tours, and the areals of tourism importance, as well as the absence of needed paths intended for tourists;

- Weak organization of tourism infrastructure in the places with attractive natural landscape;

- Absence or very small number of working qualified guides, closely familiar with local territories of administrative regions;

- Unorganized and unregulated character of nature use, which is responsible for the related pollution by domestic wastes, and the emergence of unremoved garbage, as well as careless and indifferent attitude of residents and facilities in regard to the environment.

Organization of local tours makes necessary to study available resources as a first stage. The main routes of the Sheki-Zagatala region include the BakuBalakan line, and the routes to the Gabala, Oghuz, Sheki, Gakk, Zagatala and Balakan regions. At present, the local tours are functioning in the Gabala, Sheki, Gakh and Zagatala regions (Decision of Ministry 2003). The main emphasis is laid on the efficient use of leisure-time of visitors, and the giving of broad information about the region.

The Second Program on tourism development (2010-2014) was aimed to make considerable changes on development of this sector (State Program 2010). Special attention in this Program was paid on the evaluation of the tourism potential and the preparation of local routes in the region. From this view, the planning and diversification as well as advertising of local routes continue to be a topical issue for the Sheki-Zagatala region.

\section{SUBSTANTIATION OF TOURISM ROUTES AS PREFERENTIAL TOURS}

The offered tours usually cross unique natural places and samples of heritage. In this connection, the Gabala region offers more tours. These tours include the Gabala-Bum-Gamarvan natural and ethnographic tour, the Gabala-Nohurgishlag-Vandam-Hazra natural and historical tour, and also the Gabala-Mirzabayli-Nij-Chukhur Gabala-Dizahli historical, ethnographic and environmental tour. 
The local tours, organized in Sheki typically encompass places of historical, ethnographic and environmental importance. These tours are being organized by Tourism Department of Sheki and also the local tourism institutions. Historical monuments are situated closer each other in Sheki city, and therefore, visiting of historical monument is favorable and convenient here.

The new routes of tourism which would pass through places of traditional handicraft and national heritage are recommended as follows.

1) Sheki-Okhud-Kish;

2) Sheki-Gakh-Gakhbash-Ilisu;

3) Gakh-Lakit-Gulluk;

4) Gakh-Zagatala-Jar-Mukhakh-Yukhari Chardakhar.

In practice, the organization and extension of nature-oriented tours in Sheki-Zagatala can be managed due to their vicinity to with the major tourism routes. Such factors as the existence of reserved areas, and also Shahdagh National Reserve to the south, and the existence of unique natural places in mountainous areas are regarded as advantages in terms of organization of natureoriented tours. Moreover, this kind of tour typically passes the territories of a few administrative regions. From this view, the organization of 'combined tours' seems advisable. This may allow attract tourists in much number.

Taking into consideration local recreational and tourism resources of the Sheki-Zagatala region, the following combined routes are recommended:

1) Sheki-Kish-Markhal-Khan yayla;

2) Sheki-Inja-Kondelen-Bash Goynuk-Bash Layisgi-Shin;

3) Sheki-Bichanak-Gakh-Ilisu-Saribash;

4) Gakh-Gapichay-Lakit-Lakit Kotuklu-Gumbash Peak;

5) Gabala-Bum-Gamarvan-Shahdagh National Park.

In general, the fact that most of visitors in Sheki-Zagatala are domestic tourists, is positive condition in terms of efficiently organizing local tours. In 2013, the number of tourists visiting Sheki-Zagatala exceeded 67 thousand people. More than half of this visitors used services of accommodations. Here it is notable that tourism companies may offer local tours based on contracts concluded with hotels and other accommodation centers in Sheki-Zagatala. As we think, based on the experience of Turkey in this field (Ahipaşaoğlu, Arıkan 2005), it is possible to involve $35-40 \%$ of clients of accommodations to local tours in the region. Due to this activity, based on corporative interests, tourism companies may gain additional income as well as agitate the Sheki-Zagatala as tourism region. 


\section{CoNCLUSION}

Thus, Sheki-Zagatala has a huge potential to develop its tourism industry and conduct new routes, useful in attracting much number of tourists. The geographical condition, natural and other required resources enable the implementation of such activity. As for profitability of companies responsible for organizations of these tours, this is determined below.

Profitability of organizing local tours in Sheki-Zagatala region is measurable based on the above-mentioned formula which can be applied in practice. Profitability can be calculated as economic rent per tour when main and changing expenses, and also incomes of a company must be taken into account. Permanent expenditures are composed of costs for accommodation, catering and transportation whereas variable expenditure includes payments for visiting museums or amusement parks.

For a potential company interested in organizing a tour in Sheki-Zagatala, the calculation of profitability per one tourist can be conducted as follows (1 AZN (Azerbaijani manat) equates 0,95 USD):

Accommodation fee is $25 \mathrm{AZN} /$ day (including breakfast), payment for meal is $12 \mathrm{AZN} /$ day, bus ticket is $6 \mathrm{AZN} / \mathrm{day}$, payment for guide service is $3 \mathrm{AZN} / \mathrm{day}$, whereas changing costs is considered at 2,5AZN. Considering number of participants of an organized tour lowest, profitability for a company organizing this tour must be measured as:

$$
\mathrm{K}=46 \mathrm{AZN} /(46 \mathrm{AZN}+15 \%-2,5 \mathrm{AZN}) \cdot 100=91 \mathrm{AZN} .
$$

So, profitability in organizing tour can be reached if 91 out of 100 tourists will buy the tour, sold by a company. As this calculation shows, sufficient number of tourists can be attracted to tours organized in the region, and this is beneficial. Therefore, marketing and advertising should be implemented for the purpose of increasing practical importance of the routes.

In terms of efficiently organizing tours, landscape potential of territory, the samples of national heritage must be used in common in the process of organization of tours in the Sheki-Zagatala region. Meanwhile, it is profitable in practice if $50 \%$ of customers of the hotels and other centers of accommodation will contribute to organization of tours shown in this paper. In this connection, scheme of planning of new routes should be mapped and certified due to col- 
laboration of representatives of Ministry of Culture and Tourism with experts of this field. In the meantime, tourism potential of the territories must be assessed. In order to make the routes more advantageous in practice, the related advertising works and marketing activity must be conducted and expanded. The tours should be broadly presented.

Tours can be offered to customers based on cooperation between tourism sub-agencies and accommodations. In this regard, info-tours and fam-tours should be organized as a necessary step. New local tourism routes must be presented to foreigners who visit the region with support of tourism departments of the administrative regions.

\section{REFERENCES}

Ahipaşaoğlu S., Arıkan I. (2005), Enterprises of travel industry and tourism research on agents, Ğazi, Ankara.

Dargahov V. S., Karimov R.N. (2012), Rural tourism: realization, development and opportunities. International scientific conference "Challenges to tourism in the XXI century", Sofia, 189-195.

Dargahov V. S. (2008), Recreation and tourism resources. MBA, Baku.

Dargahov V. S. (2012), Strategic planning of development of tourism in the regions. Society of Fellow Researchers, Postgraduate Students and Masters at Center of Intelligence of the Youth, National Academy of Sciences of Azerbaijan, Baku, 6, 122-132.

Decision of Ministry of Youth, Sport and Tourism on confirmation of main and additional tourism routes in Azerbaijan (2003), Newspaper of "Azerbaijan", \#14.

Durovich A. P. (2012), Marketing in tourism, INFRA-M, Moscow.

Economic passport of the Sheki-Zagatala economic region (2012), Report of Centre of Economic Reforms, Baku, http://www.ier.az/upload/file/03_Sheki-Zaqatala_A_Designed.pdf (accessed: 25.03.2015).

Ilyina Y. N. (2004), Activity of tourism agencies. Tourism market and entrepreneurship, Moscow.

Ilyina Y. N. (2002), Tour-operating: strategy and finance, Moscow, http://www.elobook.com/turist/4370-ilina-en-turoperejting-strategiya-i-finansy.html (accessed: 14.03.2015).

State Program on development of tourism in Azerbaijan Republic (2010-2014), Newspaper of "Azerbaijan" (2010), \#5, http://www.e-qanun.az/alpidata/framework/ data/19/c_f_19342.html (accessed: 09.04.2015).

Statistics of tourism (2014), State Statistical Committee of Azerbaijan Republic, Baku.

Technical support for development of tourism strategy in Azerbaijan (2006), Caspian Group Consulting, Baku.

Tourism in Azerbaijan (2006), Statistical yearbook of Azerbaijan Statistical Committee, Baku. 
Ushakov D. S. (2006), Applied tour operating. MapT, Moscow.

Yemelyanov B. V. (2007), Excursion studies. Sovetskiy Sport, Moscow.

Zdorov A. B. (2007), Economy of tourism. Finansi i statistika, Moscow. 